\title{
Incidence of systemic granulomatosis is modulated by the feeding sequence and type of enrichment in meagre (Argyrosomus regius) larvae
}

Running title: Nutritional prevention of granulomatosis in meagre larvae

Ruiz, M.A. ${ }^{1}{ }^{*}$, Hernández-Cruz, C.M. ${ }^{1}$, Caballero M.J. ${ }^{1}$, Fernández-Palacios, H. ${ }^{1}$, Saleh, R. ${ }^{1,3}$, Izquierdo, M.S. ${ }^{1}$, Betancor, M.B. ${ }^{2}$

${ }^{1}$ Aquaculture Research Group (GIA), Instituto Ecoaqua, Universidad de Las Palmas de Gran Canaria, PCTM, Crta. Taliarte s/n, 35214, Telde, Spain.

${ }^{2}$ Institute of Aquaculture, Faculty of Natural Sciences, University of Stirling, Stirling FK9 4LA, United Kingdom.

${ }^{3}$ Oceanography Department, Faculty of Science, Alexandria University, Moharram Bek, Alexandria Egypt.

*Corresponding author: miguel.ruiz106@alu.ulpgc.es

This is the peer reviewed version of the following article: Ruiz García MÁ, HernándezCruz CM, Caballero MJ, et al. Incidence of systemic granulomatosis is modulated by the feeding sequence and type of enrichment in meagre (Argyrosomus regius) larvae. Aquaculture Research 2019;50:284-295, which has been published in final form at https://doi.org/10.1111/are.13896. This article may be used for non-commercial purposes in accordance With Wiley Terms and Conditions for self-archiving. 


\begin{abstract}
Systemic granulomatosis is the most frequent disease in juvenile and adult meagre, but studies regarding the first appearance of granulomas in larvae do not exist. In order to evaluate this, meagre larvae were fed four different feeding regimes as follows: RS and RO (rotifer enriched with Easy DHA Selco or Ori-Green from 3-30 dph, respectively), RAS and RAO (rotifer enriched with Easy DHA Selco or Ori-Green from 3-21 dph and Artemia enriched with Easy DHA Selco or Ori-Green from 12-30 dph, respectively). All treatments were also fed with commercial microdiet from 20-30 dph. At $30 \mathrm{dph}$ weight, length, specific growth rate and survival was significantly higher in Artemia-fed larvae, regardless of the enrichment. Microscopic first appearance of granulomas was observed in 20 dph larvae fed RS and RO. At 30 dph granulomas and thiobarbituric acid reactive substances (TBARS) values were significantly higher in RS and RO-fed larvae than in RAS and RAO-fed larvae. The results showed that granulomas first appeared in meagre larvae at $20 \mathrm{dph}$ when fed rotifers only. Conversely, a reduced appearance of granulomas and lipid peroxidation occurs when Artemia is included in the feeding sequence reinforcing the hypothesis of a nutritional origin of the systemic granulomatosis.
\end{abstract}

Keywords: Systemic granulomatosis, meagre larvae, vitamin E, Artemia, Rotifer, feeding sequence. 


\section{Introduction}

Meagre (Argyrosomus regius) is one of the fast-growing species proposed as a candidate for marine fish diversification on commercial aquaculture in Mediterranean and Eastern Atlantic coasts, mainly due to attractive attributes for the market such as large size, good processing yield (Jiménez, Pastor, Grau, Alconchel \& Cárdenas, 2005; Duncan et al., 2013), low fat content, excellent taste (Poli et al., 2003), firm texture and great capacity to adapt to captivity (El-Shebly, El-Kady, Hussin \& Yeamin Hossain, 2007). Nevertheless, one of the most critical points in meagre production is the fish health considering the systemic granulomatosis as the more frequent disease in this species (Ghittino et al., 2004). The pathology is characterised by the presence of multiple granulomas in several tissues being liver, heart and kidney the most affected organs (Ruiz et al., 2018). Although systemic granulomatosis is a disease of unknown aetiology, there is evidence that it could be triggered by a nutritional imbalance (Ruiz et al., 2018; Cotou et al., 2016).

In the last years the studies on first life stages of meagre have been focused on larval density (Estevez, Treviño \& Gisbert, 2007; Roo, Hernandez-Cruz, Borrero, Schuchardt \& Fernandez-Palacios, 2010), live prey feeding sequence (Roo et al. 2010) and light conditions (Vallés \& Estévez 2013) in order to standardize the culture protocols. Additionally, El Kertaoui et al. (2017) studied the effect of vitamin E and C on growth parameters and in the fatty acids protection against oxidation in meagre larvae, while the omega 3 (n-3) polyunsaturated fatty acids (PUFA) requirement has been recently studied by Carvalho et al. (2018). However, there is not any study evaluating the relationship between nutrients and the appearance of systemic granulomatosis in meagre larvae.

The first live feed traditionally used in intensive aquaculture are rotifers (Brachionus spp.) due to their small body size (Theilacker \& McMaster 1971; Støttrup, 2000). Rotifer are fed by filtration making it easy to enrich, furthermore they have high population growth rate at high density. In a later stage of development, when the mouth of the larvae is big enough, Artemia nauplii are used as a live prey. However, rotifer and Artemia do not cover all of the larvae nutritional requirements and for that reason it is necessary to enrich the live food in order to improve nutritional value for the marine fish larvae (Boglino et al., 2012). Presently, commercial production of meagre involves the use of both rotifers and Artemia, although the effect that these feeding sequences might have on the development and appearance of systemic granulomatosis is unknown. 
Marine fish larvae have high requirements for long chain (LC) PUFA, namely eicosapentaenoic (20:5n-3; EPA) and docosahexaenoic acids (22:6n-3; DHA). Given that these fatty acids are highly unsaturated and thus at risk of suffering oxidation, fish larvae are more susceptible to suffering peroxidative attack than adults (Hamre, Krossoy, Lock \& Moren, 2010). Reactive oxygen species (ROS) include oxygen ions, free radicals (superoxide and hydroxyl radicals), and peroxides (hydrogen peroxide) are normal products of the oxygen metabolism (Cadenas, 1989). There are enzymes capable to neutralize ROS, some of the most important are superoxide dismutase, catalase and glutathione peroxidase. Non-enzymatic compounds, such as vitamin $\mathrm{C}$ and $\mathrm{E}$, are also powerful antioxidants (Montero et al., 1999; Ai et al., 2006; Betancor et al., 2012; Gao, Koshio, Ishikawa, Yokoyama \& Edward, 2014). In this sense, high concentrations of vitamin $\mathrm{C}$ and $\mathrm{E}$ have been detected in fish eggs indicating the importance of these micronutrients during fish early development (Hemre, Mangor-Jensen \& Lie, 1994; Lie, Sandvin \& Waagbø, 1994; Mukhopadhyay, Chattopadhyay \& Mitra, 2003; Skřivan, Marounek, Englmaierová \& Skřivanová, 2013). The requirements for vitamins C and E given by NRC (2011) for fish are 30 and $25-120 \mathrm{mg} \mathrm{kg}^{-1}$, respectively but the supplementation with extra dosage of both vitamins has proved to reduce mortality, oxidative stress as well as to improve growth in fish larvae (Stéphan, Guillaume \& Lamour, 1995; Merchie, Lavens \& Sorgeloos, 1997; Kolkovski et al., 2000).

On the other hand, typical visceral granulomatosis has been experimentally induced in turbot (Scophthatmus maximus) fed diets deficient in vitamin C (Messager, Ansquer, Metailler \& Person-Le-Ruvet, 1986). Also in turbot, Coustans, Guillaume, Metailler, Dugornay \& Messager, (1990) confirmed the role of ascorbic acid deficiency in the development of visceral granulomatosis and showed that the pathological condition was exacerbated by hypovitaminosis of B - complex. Vitamin C deficiency has also been responsible for the appearance of granulomatosis in the kidney of sea bream (Sparus aurata) (Alexis, Karanikolas \& Richards, 1997). Ruiz et al. (2018) observed that high dietary levels of vitamin $\mathrm{C}, \mathrm{E}$ and $\mathrm{K}$ reduced the severity and incidence of systemic granulomatosis in meagre.

The objective of the present study was to evaluate the first appearance and incidence of systemic granulomatosis in meagre larvae. In order to do so, meagre larvae were fed rotifers enriched with two different commercial products with divergent levels of vitamins and with or without Artemia in the feeding sequence. This study will help to understand when the systemic granulomatosis first appears in the life cycle on meagre. 


\section{Material and methods}

\subsection{Fish}

Meagre eggs were obtained from an induced spawning from broodstock from the ECOAQUA facilities at University of Las Palmas de Gran Canaria (ULPGC; Telde, Canary Islands, Spain) where the experiment was carried out. Eggs were volumetrically counted and set into 12 light grey colour cylindrical fibreglass tanks (4 triplicate treatments) of 1701 capacity at a density of $50 \mathrm{egg}^{-1}$. All tanks were equipped with continuous aeration and supplied with filtered UV-sterilized seawater at an increasing rate from $5 \% \mathrm{~h}^{-1}$ to a $100 \% \mathrm{~h}^{-1}$, to guarantee good water quality during the trial. Water entered the tanks at the bottom and exited at the surface. Oxygen (4.5-6.5 $\mathrm{g} \mathrm{l}^{-1}$ ), salinity $\left(0.034 \mathrm{mg} \mathrm{l}^{-1}\right)$ and temperature $\left(24.6\right.$ to $\left.25.3^{\circ} \mathrm{C}\right)$ was daily measured. Photoperiod was kept at $12 \mathrm{~h}$ light: $12 \mathrm{~h}$ dark by fluorescent lights. The microalgae (Nannochloropsis sp.) was added to tanks at a density of $3 \times 10^{6}$ as green water, providing nutrients directly to the larvae, contributing to the preservation of live prey nutritional quality, promoting changes in visual contrast of the medium and minimizing the exposure to light, improving water quality reducing ammonium ion concentrations as well as increasing dissolved oxygen concentrations (Øie, Makridis, Reitan \& Olsen, 1997; Reitan, Rainuzzo, Øie, \& Olsen, 1997; Huervana, De La Cru \& Caipang, 2006; Nakase et al., 2007; Stuart \& Drawbridge, 2011).

All procedures were conducted in accordance with the regulations set forward by the Spanish RD 53/2013 (BOE 8th February 2013) and the Directive 2010/63/EU of the European Parliament and of the Council of 22 September 2010 on the protection of animals used for scientific purposes. The experiment was subjected to ethical review by the Animal Welfare and Bioethical Committee at the University of Las Palmas de Gran Canaria (OEBA-ULPGC 06/2018).

\subsection{Dietary trial}

The feeding trial was performed in triplicate tanks and rotifers (Brachionus sp.) or Artemia sp. nauplii (Type AF, INVE, Dendermonde, Belgium) were enriched with different products. Rotifers (R) and Artemia (A) were enriched with either Easy DHA Selco (S; INVE, Dendermonde, Belgium) or Ori-Green (O; Skretting, Norway), giving place to four dietary treatments: RAS, RAO, RS and RO. Additionally inert microdiets 
were used (Gemma Micro 150 and $300 \mu \mathrm{m}$; Skretting, France) at the end of the feeding experiment (from 20 to 30 dph; Table 1, Supplementary Figure 1) .

Larvae were fed with enriched rotifers twice daily (9:00 and 14:00) from 3 to 21 (RAS and RAO treatments) or 3 to 30 (RS and RO treatments) days post hatching (dph). Larvae fed diets RAS and RAO were fed enriched Artemia twice daily (11:00 and 15:00) from 12 to $30 \mathrm{dph}$. Additionally, larvae from all the dietary treatments were co-fed with inert microdiets from 20 to $30 \mathrm{dph}$ at a feeding rate of $10-15 \%$ of the biomass.

Table 1. Meagre (Argyrosomus regius) larvae feed sequence from $3 \mathrm{dph}$ to $30 \mathrm{dph}$.

\begin{tabular}{|c|c|c|c|c|c|}
\hline TREATMENT & RAS & RAO & RS & RO & Feed added \\
\hline \multicolumn{6}{|c|}{ Day post hatch (dph) } \\
\hline Phytoplankton & $3-18$ & $3-18$ & $3-30$ & $3-30$ & 300.000 cells ml ${ }^{-1}$ \\
\hline $\begin{array}{l}\text { Enriched } \\
\text { Rotifer }\end{array}$ & $3-21$ & $3-21$ & $3-30$ & $3-30$ & 10 ind $\mathrm{ml}^{-1}$ \\
\hline Enriched Artemia & $12-13$ & $12-13$ & - & - & 0.5 ind $\mathrm{ml}^{-1}$ \\
\hline Enriched Artemia & $14-30$ & $14-30$ & - & - & 1.3-1.5 ind $\mathrm{ml}^{-1}$ \\
\hline $\begin{array}{l}\text { Microdiet 150-300 } \\
\mu \mathrm{m}(50 \%)\end{array}$ & $20-30$ & $20-30$ & $20-30$ & $20-30$ & $1.5-2 \mathrm{~g}$ \\
\hline
\end{tabular}

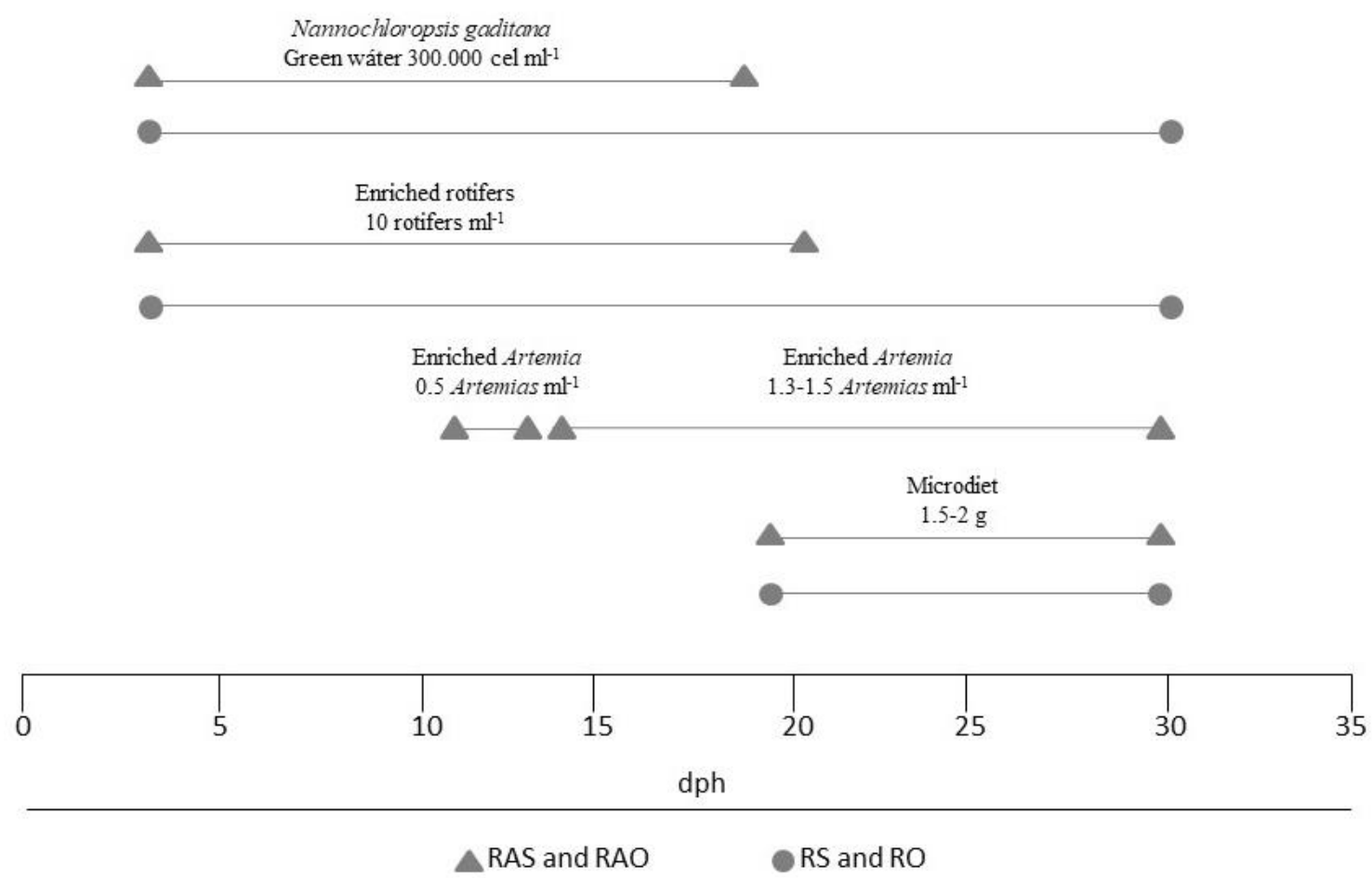

Supplementary Figure 1 Meagre (Argyrosomus regius) larvae feed sequence from $3 \mathrm{dph}$ to $30 \mathrm{dph}$. 


\subsection{Live prey culture and enrichment protocol}

Rotifers and Artemia were cultured at the ECOAQUA facilities at the University of Las Palmas de Gran Canaria (ULPGC; Telde, Canary Islands, Spain). Rotifers were cultured at a density of 400 rotifers $\mathrm{ml}^{-1}$ in $500 \mathrm{~L}$ enrichment troncoconical-tanks. Enrichment tanks were well aerated $\left(5 \mathrm{mg} \mathrm{l}^{-1} \mathrm{O}_{2}\right)$ with filtered and UV-treated seawater $\left(0.037 \mathrm{mg} \mathrm{l}^{-1}\right)$. Rotifer were enriched with Ori-Green $\left(0.15-0.25 \mathrm{~g}\right.$ million $^{-1}$ rotifers, RO dietary treatment) for two hours before being fed to the meagre larvae or with Easy DHA Selco ( $0.6 \mathrm{~g} \mathrm{l}^{-1}$, RS dietary treatment) for 24 hours.

Artemia cysts were hatched at $27^{\circ} \mathrm{C}$ and $0.030 \mathrm{mg} \mathrm{l}^{-1}$ salinity until $100 \%$ hatch was achieved. Then they were rinsed with sea water and transferred to a culture tank at $24^{\circ}$ C. Artemia was enriched with Ori-Green (0.8 $\mathrm{g} \mathrm{million}^{-1}$ Artemia, RAO dietary treatment) for 12 hours or with Easy DHA Selco (0.6 g million ${ }^{-1}$ Artemia, RAS dietary treatment) for 24 hours before being fed to the larvae.

During the co-feeding period micro-diets Gemma Micro 150 and 300 (Skretting, France) were used ( $15 \%$ biomass $\left.\mathrm{d}^{-1}\right)$. Composition and fatty acid profile of all dietary treatments is shown at Tables 2 and 3.

Table 2. Ingredients, fatty acid composition and gross composition of the enrichment and inert microdiet fed to meagre (Argyrosomus regius) larvae.

\begin{tabular}{|c|c|c|c|}
\hline & Easy DHA Selco & Ori-green & Micro-diet \\
\hline Proteins (\%) & 27 & 43 & 59 \\
\hline Lipids (\%) & 67 & 30 & 14 \\
\hline Vitamin A $\left(\mathrm{IU} \mathrm{kg}^{-1}\right)$ & $1.500,000$ & 350 & 23,000 \\
\hline Vitamin $\mathrm{D}_{3}\left(\mathrm{IU} \mathrm{kg}^{-1}\right)$ & 150,000 & 50 & 2,800 \\
\hline Vitamin $E\left(\mathrm{mg} \mathrm{kg}^{-1}\right)$ & 3,600 & 4,000 & 400 \\
\hline Vitamin $C\left(\mathrm{mg} \mathrm{kg}^{-1}\right)$ & 800 & - & 1,000 \\
\hline \multicolumn{4}{|l|}{ Fatty acids (\%) } \\
\hline 14:0 & 3,66 & 1,87 & 1.89 \\
\hline 16:0 & 15,89 & 20,14 & 17.79 \\
\hline 18:0 & 4,09 & 5,26 & 3.59 \\
\hline 20:0 & 0,29 & 0,46 & 0.21 \\
\hline$\Sigma$ Saturated $^{\dagger}$ & 24,76 & 28,37 & 23.9 \\
\hline $16: 1 \mathrm{n}-7$ & 5,07 & 2,81 & 2.41 \\
\hline $18: 1 \mathrm{n}-9$ & 23,75 & 16,44 & 13.83 \\
\hline $18: 1 n-7$ & 3,10 & 2,05 & 2.23 \\
\hline $20: 1 n-7$ & 3,48 & 1,26 & 2.22 \\
\hline $22: 1 n-11$ & 2,74 & 0,64 & 1.89 \\
\hline$\Sigma$ Monosaturated $^{\ddagger}$ & 39,97 & 24,39 & 23.8 \\
\hline $18: 2 n-6$ & 8,68 & 14,28 & 28.14 \\
\hline $18: 3 n-6$ & 0,21 & 0,21 & 0.08 \\
\hline
\end{tabular}




$\begin{array}{lccc}20: 2 n-6 & 0,42 & 0,25 & 0.23 \\ 20: 3 n-6 & 0,12 & 0,10 & 0.05 \\ 20: 4 n-6 & 0,93 & 1,38 & 0.71 \\ \boldsymbol{\Sigma} \text { n-6PUFA } & 10,60 & 16,50 & 29.3 \\ 18: 3 n-3 & 1,98 & 2,55 & 3.18 \\ 18: 4 n-3 & 0,91 & 0,41 & 0.69 \\ 20: 3 n-3 & 0,19 & 0,16 & 0.13 \\ 20: 4 n-3 & 0,76 & 0,36 & 0.27 \\ 20: 5 n-3 & 5,13 & 4,21 & 4.79 \\ 22: 5 n-3 & 1,78 & 1,16 & 0.68 \\ 22: 6 n-3 & 12,08 & 20,77 & 12.28 \\ \boldsymbol{\Sigma} \text { n-3PUFA } & 22,84 & 29,59 & 22.0 \\ \text { (n-3+n-6) PUFA } & 10,60 & 16,50 & 51.3 \\ \text { Total n-3 LC-PUFA } & 1 \dagger & 26.5 & 18.02\end{array}$

${ }^{+}$Includes 15:0 and 17:0. ${ }^{\ddagger}$ Includes 14:1n-7. 14:1n-5. 15:1n-5. 16:1n-5. 18:1n-5. 20:1n-9. and 20:1n-5. ${ }^{\S}$ Includes. 22:5n-6 and 22:4n-6. "Includes 16:3n-3 and 16:4n-3. ${ }^{+\dagger}$ LC- PUFA, long-chain polyunsaturated fatty acid (sum of 20:4n-3, 20:5n-3 22:5n-3 and 22:6n-3).

Table 3. Fatty acid composition (percentage of total fatty acids), proximate composition and vitamin E and C content of Artemia (A) and rotifers (R) enriched with either Easy DHA Selco (S) or Ori green (O) used to feed meagre (Argyrosomus regius) larvae.

\begin{tabular}{|c|c|c|c|c|}
\hline Fatty acids (\%) & AS & AO & $\mathbf{R S}$ & RO \\
\hline $14: 0$ & 0.90 & 0.61 & 2.05 & 1.66 \\
\hline $16: 0$ & 11.32 & 11.23 & 12.83 & 10.14 \\
\hline 18:0 & 6.53 & 6.07 & 5.55 & 3.70 \\
\hline $20: 0$ & 0.22 & 0.19 & 0.19 & 0.14 \\
\hline$\Sigma$ Saturated $^{\dagger}$ & 20.1 & 19.2 & 22.1 & 17.0 \\
\hline $16: 1 n-7$ & 2.33 & 1.80 & 12.35 & 15.76 \\
\hline $18: 1 n-9$ & 21.77 & 18.29 & 22.95 & 18.71 \\
\hline $18: 1 n-7$ & 6.09 & 5.66 & 5.47 & 4.05 \\
\hline $20: 1 n-7$ & 1.49 & 0.72 & 2.63 & 2.90 \\
\hline $22: 1 n-11$ & 0.60 & 0.04 & 0.96 & 0.56 \\
\hline$\Sigma$ Monosaturated $^{\ddagger}$ & 34.0 & 28.4 & 49.0 & 46.4 \\
\hline $18: 2 n-6$ & 6.12 & 6.38 & 8.89 & 12.85 \\
\hline $18: 3 n-6$ & 0.50 & 0.68 & 0.19 & 0.11 \\
\hline $20: 2 n-6$ & 0.37 & 0.28 & 0.32 & 0.52 \\
\hline $20: 3 n-6$ & 0.16 & 0.13 & 0.40 & 0.83 \\
\hline $20: 4 n-6$ & 0.79 & 0.42 & 1.35 & 1.30 \\
\hline$\Sigma$ n-6PUFA & 8.0 & 7.9 & 11.4 & 15.8 \\
\hline $18: 3 n-3$ & 22.55 & 31.22 & 1.58 & 2.22 \\
\hline $18: 4 n-3$ & 4.15 & 6.03 & 0.59 & 0.21 \\
\hline $20: 3 n-3$ & 1.19 & 1.46 & 0.11 & 0.14 \\
\hline $20: 4 n-3$ & 0.97 & 1.11 & 0.66 & 0.56 \\
\hline $20: 5 n-3$ & 3.29 & 1.11 & 4.05 & 3.98 \\
\hline $22: 5 n-3$ & 0.59 & 0.09 & 1.40 & 1.20 \\
\hline $22: 6 n-3$ & 3.54 & 1.31 & 5.92 & 8.48 \\
\hline$\Sigma$ n-3PUFA & 36.3 & 42.3 & 14.3 & 16.8 \\
\hline
\end{tabular}




\begin{tabular}{|c|c|c|c|c|}
\hline$(n-3+n-6)$ PUFA & 44.3 & 50.2 & 25.7 & 32.6 \\
\hline Total n-3 LC-PUFA ${ }^{\dagger \dagger}$ & 8.39 & 3.62 & 12.03 & 14.22 \\
\hline \multicolumn{5}{|l|}{ Vitamins $\left(\mathrm{mg} \mathrm{kg}^{-1}\right)$} \\
\hline Vitamin E & $410.7^{\mathrm{d}}$ & $368^{c}$ & $310.1^{\mathrm{b}}$ & $189.9^{\mathrm{a}}$ \\
\hline Vitamin C & $1037.4^{\mathrm{b}}$ & $1033^{\mathrm{b}}$ & $279.8^{\mathrm{a}}$ & $287.5^{\mathrm{a}}$ \\
\hline \multicolumn{5}{|c|}{ Proximate composition (\%) } \\
\hline Protein & 53.2 & 54.5 & 49.3 & 50.3 \\
\hline Lipid & 22.4 & 20.3 & 18.3 & 17.1 \\
\hline Ash & 11.5 & 12.7 & 10.2 & 11.9 \\
\hline Moisture & 10.1 & 9.8 & 9.4 & 9.7 \\
\hline
\end{tabular}

Data expressed as means of three technical replicates per batch of diet. ${ }^{\dagger}$ Includes 15:0 and 17:0. 'Includes 14:1n-7. 14:1n-5. 15:1n-5. 16:1n-5. 18:1n-5. 20:1n-9. and 20:1n-5. \$Includes. 22:5n-6 and 22:4n-6. IIncludes 16:3n-3 and 16:4n-3. ${ }^{+\dagger}$ LC- PUFA, long-chain polyunsaturated fatty acid (sum of 20:4n-3, 20:5n-3 22:5n-3 and 22:6n-3).

\subsection{Sample collection}

Samplings were performed at day 10, 20 and $30 \mathrm{dph}$. On each sampling 50 larvae were sacrified in ice and measured for total length. After measurement, that the 50 larvae were fixed in $4 \%$ buffered formalin for histological analysis. Another 30 larvae were collected to determine dry weight at each sampling point. Additional 30 larvae were collected for biochemical and TBARS analysis and stored at $-80{ }^{\circ} \mathrm{C}$ until analysis.

\subsection{Growth and survival}

Every 10 days, 50 larvae from each tank were sampled and measured for dry weight $\left(100{ }^{\circ} \mathrm{C}\right.$ for 24 hours) and total length (TL) using a profile projector (Mitutoyo PJ3000A, Kanagawa, Japan). Final survival was determined at $30 \mathrm{dph}$ by counting remaining alive larvae in experimental tanks.

\subsection{Biochemical analysis}

Larvae and feeds biochemical composition analysis were conducted following standard procedures (AOAC, 2010). Lipids of larvae and feeds were extracted with a choloroform:methanol (2:1 v/v) mixture as described by Folch, Lees, \& Stanley Sloane, (1957).

Fatty acids from total lipids were prepared by transmethylation as described by Christie (1982). Fatty acid methyl esters (FAMES) were separated and quantified by gas- 
liquid chromatography following the conditions described by Izquierdo, Arakawa, Takeuchi, Haroun, \& Watanabe, (1992).

TBARS were measured in triplicate from extracted total fatty acids $\left(10 \mathrm{mg} \mathrm{ml}^{-1}\right)$ according to Burk, Trumble, \& Lawrence (1980). $50 \mu 1$ of $0.2 \%$ (w/v) BHT in ethanol was added to $200 \mu \mathrm{l}$ of lipid sampled. Following, $0.5 \mathrm{ml}$ of $1 \%(\mathrm{w} / \mathrm{v}) \mathrm{TBA}$ in MiliQ distillate water and $0.5 \mathrm{ml}$ of $10 \%(\mathrm{w} / \mathrm{v})$ trichloroacetic acid in MiliQ distillate water were added to the sample, all solutions were freshly prepared. All mixed reagents were mixed in a stoppered test tube and heated in dark at $100{ }^{\circ} \mathrm{C}$ for $20 \mathrm{~min}$. Then, samples were cooled in ice $5 \mathrm{~min}$ and particulate matter was removed by centrifugation at $2000 \mathrm{~g}$ (Sigma 4K15, Osterode am Harz, Germany) $5 \mathrm{~min}$. Supernatant was read in a spectrophotometer (Evolution 300, Thermo Scientific, Cheshire, UK) at $532 \mathrm{~nm}$ and recorded against a blank sample. The concentration of TBA-malondialdehyde (MDA) expressed as $\mu \mathrm{mol}$ MDA per $\mathrm{g}$ of tissue was calculated using the extinction coefficient $0.156 \mu \mathrm{M}^{-1} \mathrm{~cm}^{-1}$.

The concentration of vitamin $\mathrm{E}$ was determined in the dietary treatments (Table 3 ). The $\alpha$-TOH was injected ( $50 \mu \mathrm{l})$ in a high performance liquid chromatograph (HPLC) with UV detection at the University of Stirling (Scotland, UK). Samples were weighed, homogenized in ethanolic pyrogallol and saponified as described by McMurray et al. (1980). HPLC analysis was performed using 150 x $4.60 \mathrm{~mm}, 5 \mu \mathrm{m}$ reverse-phase Luna and C18 column (Phenomenox, CA, USA). The mobile phase was methanol:ultrapure water $(98: 2 \mathrm{v} / \mathrm{v})$ with a flow rate of $1.0 \mathrm{ml} \mathrm{min}^{-1}$ in ambient temperature. It was used a wavelength of $293 \mathrm{~nm}$ to determine the vitamin E concentrations and was achieved by comparison with $(+)-\alpha$-tocopherol (Sigma-Aldrich) as the external standard.

The concentration of vitamin $\mathrm{C}$ was determined in the dietary treatments (Table 3) as described by Betancor et al. (2012). Samples were weighed, homogenised and dissolved in $0.4 \mathrm{M}$ phosphate buffer (adjusted to $\mathrm{pH} 3.0$ with phosphoric acid). The samples were centrifuged at $3.000 \mathrm{rpm}$, supernatants removed and filtered through a disposable $0.45 \mu \mathrm{m}$ filter and stored at $4^{\circ} \mathrm{C}$ until the measurement in a HPLC with UV detection. The determination of vitamin $\mathrm{C}$ concentration was achieved by comparison with tris (cyclohexylammonium) ascorbic acid-2-phosphate (Sigma-Aldrich) as the external standard. 


\subsection{Histopathology}

In order to estimate the first appearance of granulomas, every 10 days (10, 20, 30 dph) 50 larvae per tank (150 larvae per treatment) were sacrificed in ice and fixed in $4 \%$ buffered formalin for histological analysis. The samples were dehydrated in a series of different concentrations of ethanol and embedded in a paraffin block. The samples were cut at $4 \mu \mathrm{m}$, fixed to the microscope slide, heated and finally stained with haematoxylin and eosin (H\&E), Ziehl-Neelsen (ZN) (Martoja \& Martoja-Pearson, 1970), Fite-Faraco method (Fite, Cambre, \& Turner, 1947) and Gram stain (Gregersen, 1978). Then, the samples were used for histopathological evaluation.

\subsection{Statistical analysis}

All statistical analyses were done with Statgraphics (Statgraphics Centurion XVI version 16.1.03 for Windows; Graphic Software Systems, Inc. The Plains, Virginia). Prior to statistical analysis percentage data were arsin transformed. Survival, growth, percentage of larvae with granulomas and biochemical analysis were tested for normality with the Kolmogorov Smirnov test and homogeneity of variance was performed with the Levene test. Survival, growth, percentage of larvae with granulomas and biochemical analysis data were treated by one-way ANOVA followed by Tukey post-hoc test $(\mathrm{P}<0.05)$. Growth, survival, fatty acid composition and percentage of granulomas were analysed by two-way analysis of variance (ANOVA). A significance level of 0.05 was used.

\section{Results}

\subsection{Growth and survival}

Significant differences in larvae dry weight and total length were found among the dietary treatments at $20 \mathrm{dph}$, being higher in larvae fed with Artemia regardless of the enrichment (Figure 1). This superior growth in Artemia-fed larvae was maintained at 30 dph. Specific growth rate (SGR) was significantly higher in larvae fed dietary treatments RAS and RAO (15.7 and 16.6\%, respectively) compared with those fed RS and RO (11.6 and $8.3 \%$, respectively) (Table 4). Survival was significantly higher in larvae fed with Artemia (Table 4). All these differences could be explained by the factor "live prey" as indicated by the two-way ANOVA, with "enrichment media" also affecting dry weight 
at $20 \mathrm{dph}$. No interactive effect between "live prey" and "enrichment media" was observed for any of the performance parameters.
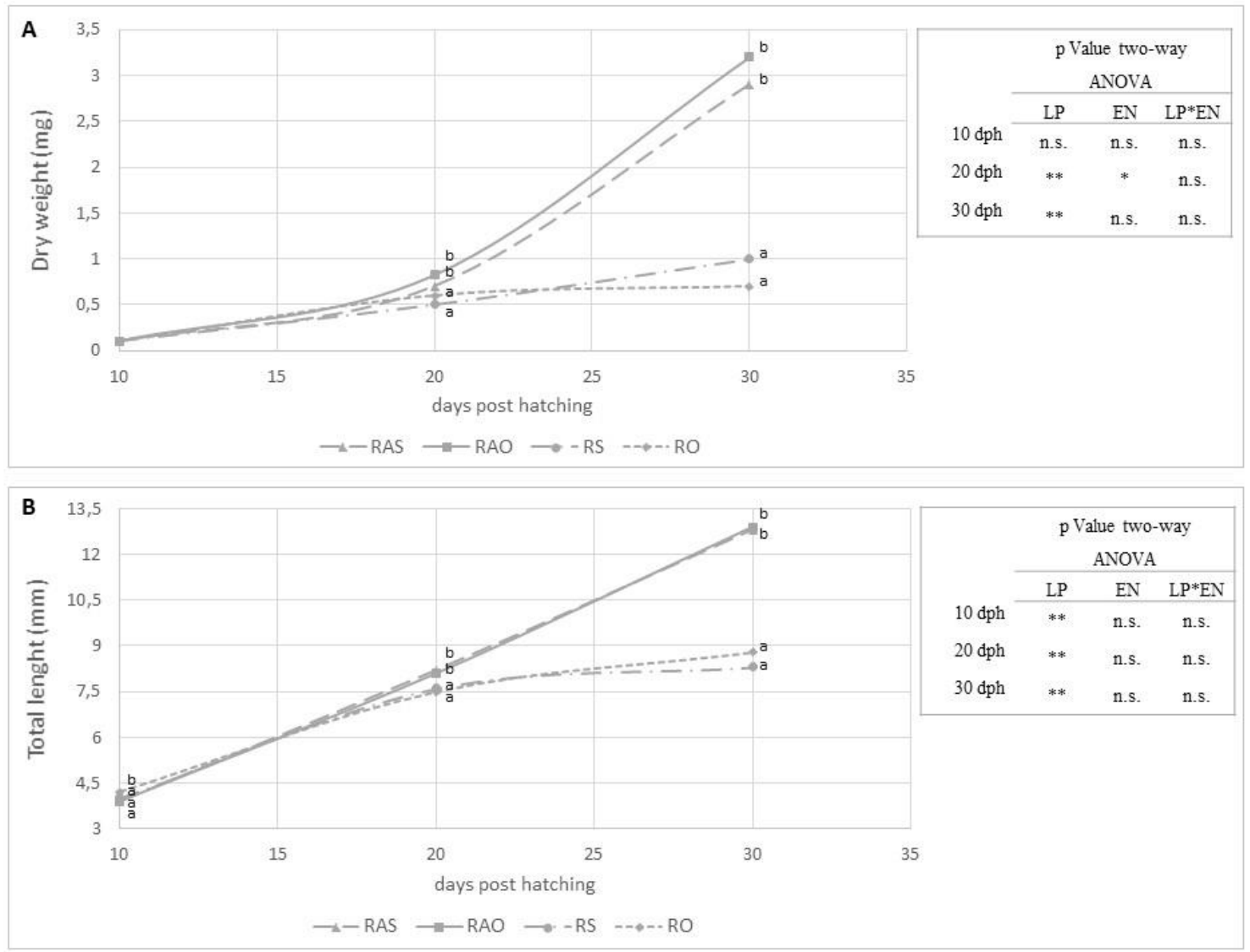

Figure 1 Meagre (Argyrosomus regius) larvae A) dry weight (mg) and B) total length (mm) after 10, 20 and 30 dph of experimental trial fed with Artemia (A) or rotifers (R) enriched with either Easy DHA Selco (S) or Ori-green (O). LP, live prey; EN, enrichment; LP*EN, interaction between live prey and enrichment. $* \mathrm{p}<0.05 * * \mathrm{p}<0.01$. 
Table 4. Proximate composition, TBARS content and meagre (Argyrosomus regius) larvae performance at the end of the experimental trial $(30 \mathrm{dph})$. Larvae were fed rotifers (R) alone or rotifers and Artemia (RA) enriched with either Easy DHA Selco (S) or Origreen $(\mathrm{O})$.

\begin{tabular}{|c|c|c|c|c|c|c|c|c|c|c|c|c|c|c|c|}
\hline \multirow{3}{*}{$\begin{array}{l}\text { Proximate } \\
\text { composition (\%) } \\
\text { Lipid }\end{array}$} & & & & & & & & & & & & & \multicolumn{3}{|c|}{ two-way Anova p } \\
\hline & \multicolumn{3}{|c|}{ RAS } & \multicolumn{3}{|c|}{ RAO } & \multicolumn{3}{|c|}{$\mathbf{R S}$} & \multicolumn{3}{|c|}{ RO } & $\mathbf{L P}$ & EN & LP*EN \\
\hline & 2.1 & \pm & 0.2 & 2.0 & \pm & 0.2 & 1.9 & \pm & 0.1 & 1.9 & \pm & 0.2 & n.s. & n.s. & n.s. \\
\hline Protein & 10.1 & \pm & 2.1 & 10.7 & \pm & 1.5 & 10.9 & \pm & 2.0 & 10.6 & \pm & 1.3 & n.s. & n.s. & n.s. \\
\hline Ash & 2.7 & \pm & 0.1 & 2.8 & \pm & 0.2 & 2.7 & \pm & 0.8 & 2.9 & \pm & 0.3 & n.s. & n.s. & n.s. \\
\hline Moisture & 82.1 & \pm & 2.8 & 82.3 & \pm & 2.1 & 82.7 & \pm & 2.2 & 82.3 & \pm & 2.7 & n.s. & n.s. & n.s. \\
\hline TBARS content $\left(\mu \mathrm{mol} \mathrm{g}^{-1}\right)$ & 67.4 & \pm & $1.9^{\mathrm{a}}$ & 56.8 & \pm & $7.1^{\mathrm{a}}$ & 288 & \pm & $15.9^{\mathrm{b}}$ & 282.9 & \pm & $11^{\mathrm{b}}$ & $* *$ & n.s. & n.s. \\
\hline SGR $(\%)$ & 15.7 & \pm & $1.3^{\mathrm{b}}$ & 16.6 & \pm & $2.3^{\mathrm{b}}$ & 11.6 & \pm & $2.5^{\mathrm{a}}$ & 8.3 & \pm & $1.1^{\mathrm{a}}$ & $* *$ & n.s. & n.s. \\
\hline Survival (\%) & 19.5 & \pm & $3.4^{\mathrm{b}}$ & 17.2 & \pm & $1.7^{\mathrm{b}}$ & 14.8 & \pm & $0.8^{\mathrm{a}}$ & 12.8 & \pm & $1.4^{\mathrm{a}}$ & $* *$ & n.s. & n.s. \\
\hline
\end{tabular}

Data expressed as means of three technical replicates per batch of larvae. SGR, specific growth rate; LP, live prey; EN, enrichment; $\mathrm{LP}^{*} \mathrm{EN}$, interaction between live prey and enrichment. Different superscript letters denote differences among treatments identified by one-way ANOVA.

$* * \mathrm{p}<0.01$

\subsection{Histopathology}

First observation of granulomas under the microscope was at $20 \mathrm{dph}$ in liver of fish fed rotifer enriched with Selco (RS; $1.3 \%$ ) and with Ori-Green (RO; $2.0 \%$ ), without significant differences (Figure 2).

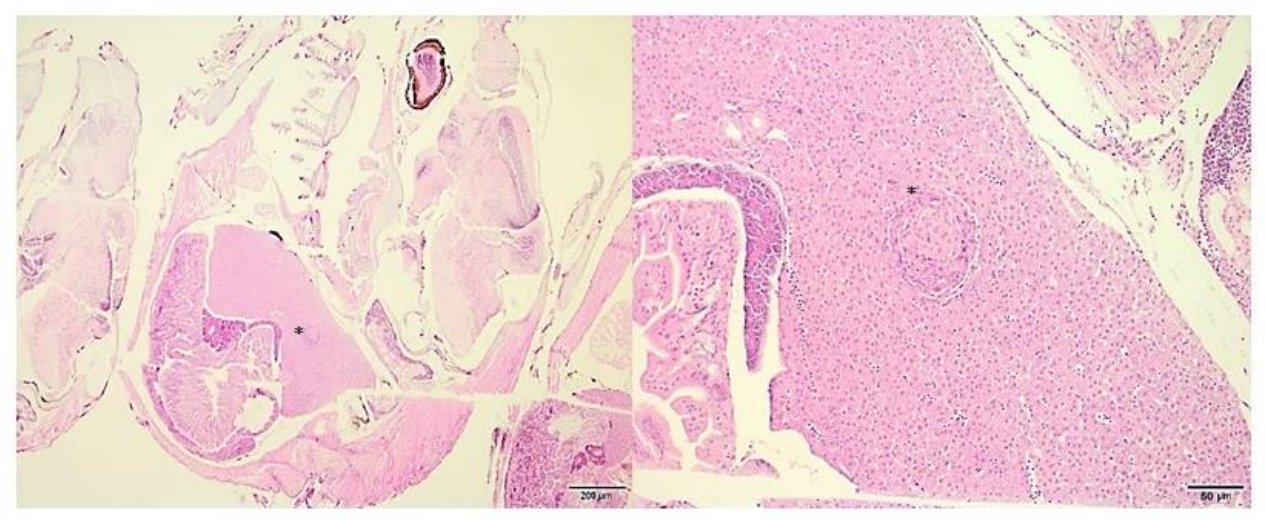

Figure 2 Granuloma in the liver of meagre larvae fed with experimental diets at $20 \mathrm{dph}$. *Microscopic granuloma. 
The incidence of granulomas in meagre larvae increased after $30 \mathrm{dph}$, mainly in larvae fed rotifer-only together with microdiet. The percentage of affected larvae with granulomas was significantly higher in RS and RO-fed larvae (10.7 and 15.3\%, respectively) compared with larvae fed RAS (0\%) and RAO (0.7\%) (Figure 3). "Live prey" was the only factor driving the differences in the appearance of granulomas at 30 dph.

\section{$\%$ of meagre larvae with granulomas}

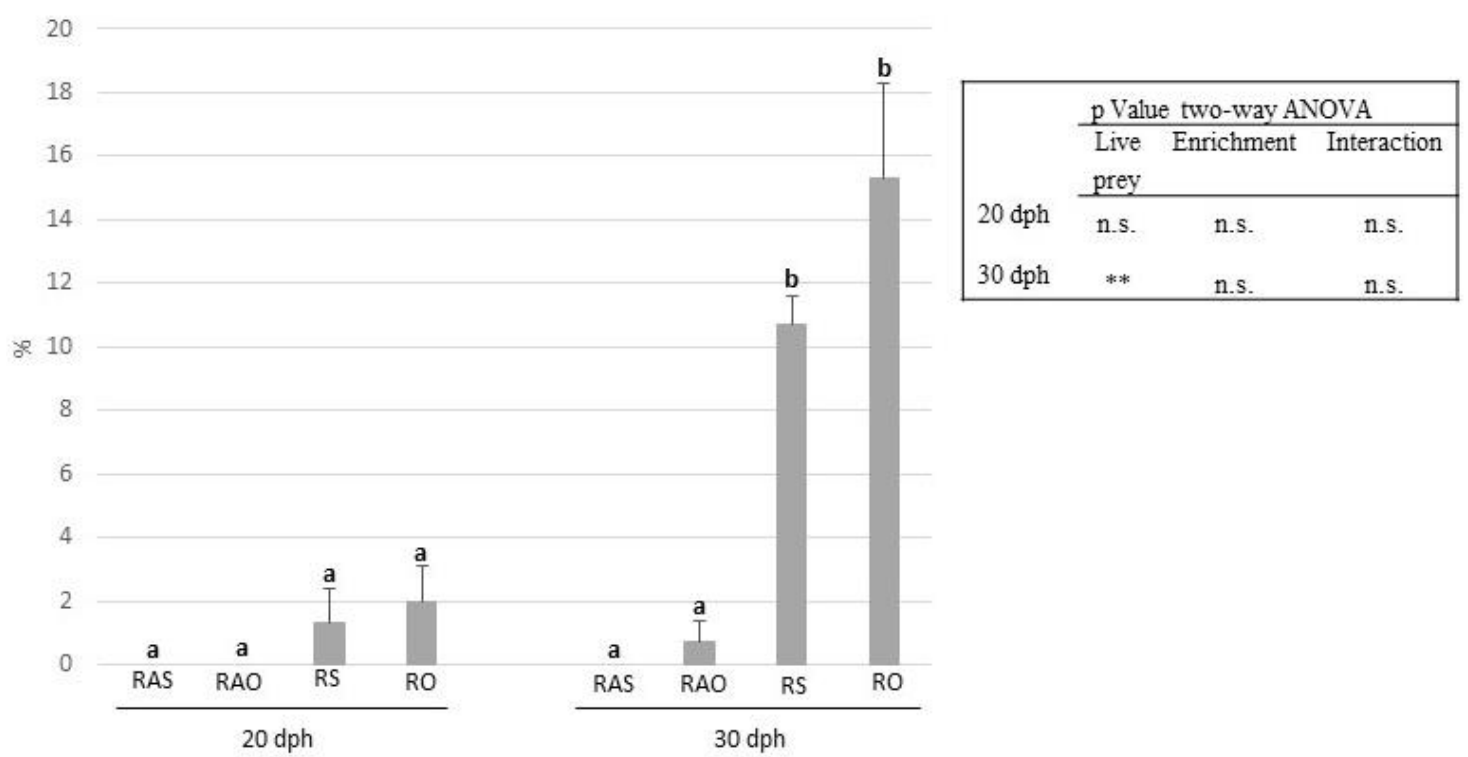

Figure 3 Incidence of granulomas (\%) in meagre larvae after feeding with Artemia (A) or rotifers (R) enriched with either Easy DHA Selco (S) or Ori-green (O) for 20 or $30 \mathrm{dph}$. Each value represents mean $\pm S D(n=600)$. Different superscript letters denote differences among treatments identified by one-way ANOVA. The inset table presents $p$ values for the effect of live prey, enrichment and their interaction on both factors on presence of granulomas.

Regarding the morphology of the granulomas, all were at initial stages of development and could be observed as isolated and irregular aggregated of macrophages with scattered lymphocytes (Figure 4A) that later were forming concentric layers with a necrotic centre (Figure 4B). The main affected organ with granulomas was liver, followed by kidney. The specific stainings (Ziehl-Neelsen, Fite-Faraco and Gram stain) were all negative, discarding a possible infectious origin (Figure 5A, 5B and 5C). 


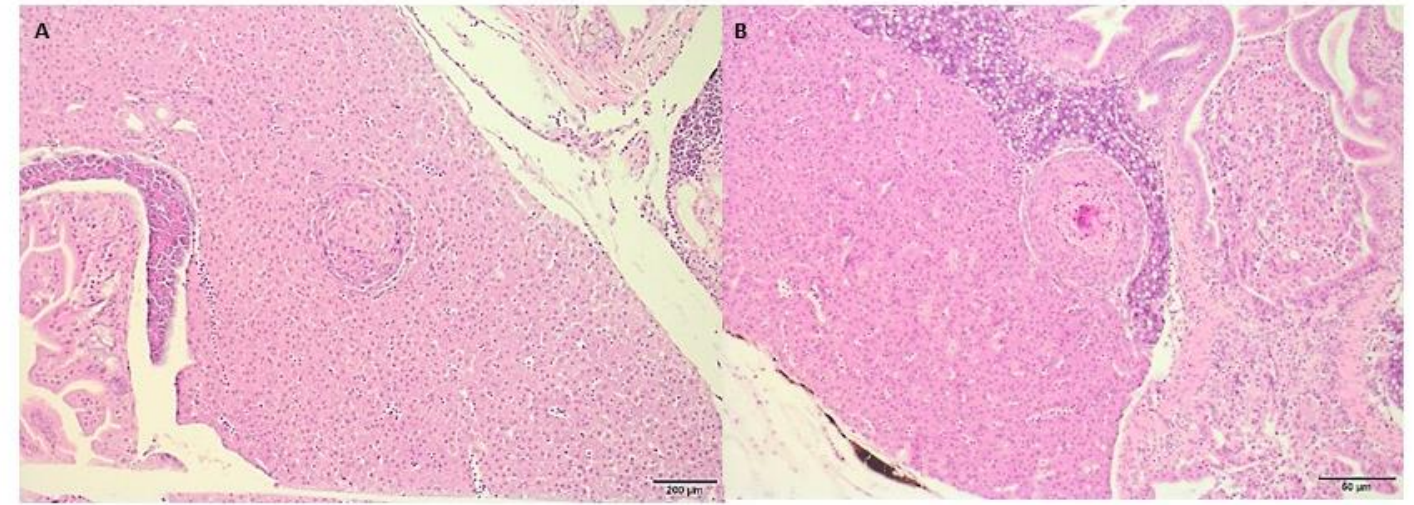

Figure 4 Different stages of granuloma development in meagre larvae of 20 and $30 \mathrm{dph}$ fed with experimental diets. A) Irregular aggregated of macrophages and inflammatory cells. B) Concentric layers of macrophages and necrotic centre.

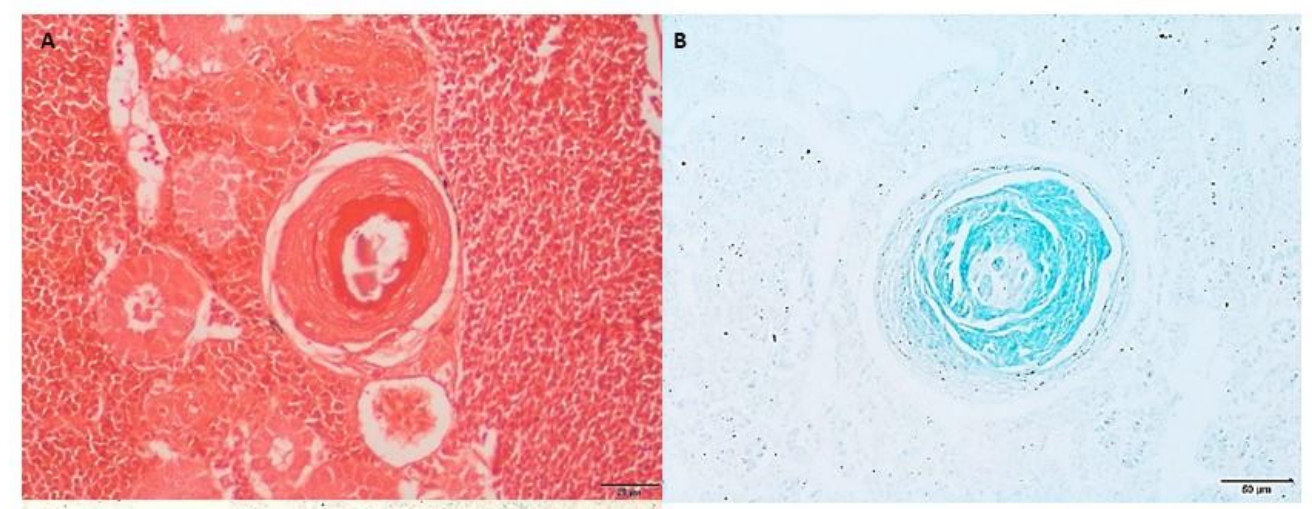

C

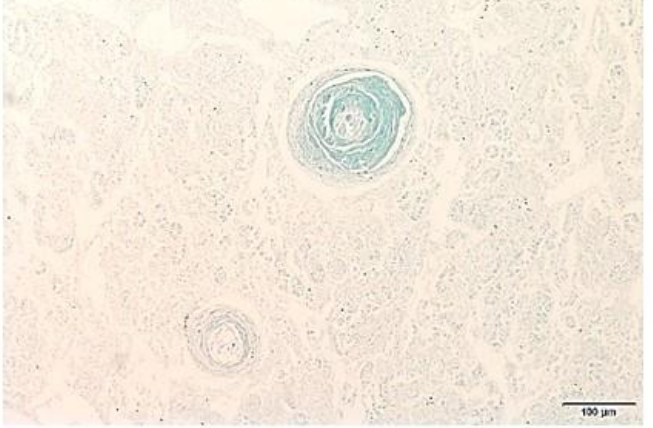

Figure 5 Negative staining in granulomas with A) Gram stain in kidney, B) Ziehl-Neelsen stain in liver and C) Fite-Faraco stain in liver.

\subsection{Whole larvae composition, TBARS content and fatty acid profiles}

There were not differences in the tissue lipid, protein or ash content among larvae fed the different experimental diets (Table 4). The level of lipid peroxides, as indicated by

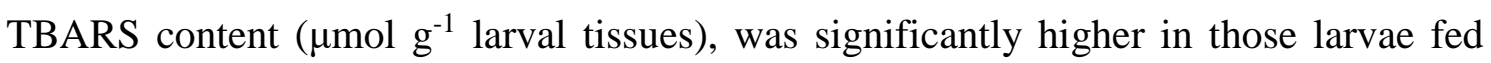


rotifer only together with microdiet (diets RO and RS) (Table 4). The factor "enrichment media" did not drive the differences observed according to the two-way ANOVA, indeed only live prey factor influenced TBARS content.

Fatty acid composition of the larvae (Table 5) generally reflected the fatty acid composition of the diet (Table 2 and 3). Meagre larvae fed RAS showed significantly higher monounsaturated fatty acids and n-9 PUFA. Larvae fed RAS and RAO had significantly higher concentration of linoleic acid (18:2n-6) and n-6. Larvae fed with rotifers only had significantly higher concentration of saturated fatty acids, arachidonic acid (ARA) and DHA. The factor "live prey" explained most of the differences in the fatty acid profile. However, an interaction between "live prey" and "enrichment media" lead to differences in the percentages of certain fatty acids such as $16: 1 n-7,22: 1 n-11$, $18: 3 n-3,20: 3 n-3$ and $20: 4 n-3$.

Table 5. Fatty acid composition (percentage of fatty acids) of meagre (Argyrosomus regius) larvae fed with experimental diets. Larvae were fed rotifers (R) alone or rotifers and Artemia (RA) enriched with either Easy DHA Selco (S) or Ori-green $(\mathrm{O})$.

\begin{tabular}{|c|c|c|c|c|c|c|c|c|c|c|c|}
\hline \multirow{3}{*}{$\begin{array}{l}\text { Fatty acids (\%) } \\
14: 0\end{array}$} & \multirow{2}{*}{\multicolumn{2}{|c|}{ RAS }} & \multirow{2}{*}{\multicolumn{2}{|c|}{ RAO }} & \multirow{2}{*}{\multicolumn{2}{|c|}{$\mathbf{R S}$}} & & & \multicolumn{3}{|c|}{ two-way Anova p } \\
\hline & & & & & & & \multicolumn{2}{|r|}{ RO } & $\mathbf{L P}$ & EN & LP*EN \\
\hline & 0.8 & $\pm 0.2^{\mathrm{b}}$ & 0.6 & $\pm 0.0^{\mathrm{b}}$ & 0.5 & $\pm 0.0^{\mathrm{a}}$ & 0.4 & $\pm 0.0^{\mathrm{a}}$ & $*$ & n.s. & n.s. \\
\hline $16: 0$ & 16.8 & \pm 0.9 & 17.0 & $\pm \quad 1.7$ & 19.5 & \pm 3.4 & 18.0 & \pm 1.7 & n.s. & n.s. & n.s. \\
\hline 18:0 & 8.0 & $\pm 0.3^{\mathrm{a}}$ & 9.8 & $\pm 1.3^{\mathrm{a}}$ & 14.1 & $\pm 1.9^{\mathrm{b}}$ & 13.5 & $\pm 1.2^{\mathrm{b}}$ & $* *$ & n.s. & n.s. \\
\hline $20: 0$ & 0.3 & $\pm 0.0^{\mathrm{a}}$ & 0.4 & $\pm 0.0^{\mathrm{a}}$ & 0.5 & $\pm 0.1^{b}$ & 0.5 & $\pm 0.0^{\mathrm{b}}$ & $* *$ & n.s. & n.s. \\
\hline$\Sigma$ Saturated $^{\dagger}$ & 26.9 & $\pm 1.5^{\mathrm{a}}$ & 28.8 & $\pm 3.1^{\mathrm{a}}$ & 35.3 & $\pm 5.6^{\mathrm{b}}$ & 33.2 & $\pm 3.0^{\mathrm{b}}$ & $*$ & n.s. & n.s. \\
\hline $16: \ln -7$ & 2.3 & $\pm 0.3^{\mathrm{b}}$ & 1.6 & $\pm 0.1^{\mathrm{a}}$ & 2.1 & $\pm 0.1^{\mathrm{b}}$ & 2.3 & $\pm 0.3^{\mathrm{b}}$ & n.s. & n.s. & $*$ \\
\hline $18: \ln -9$ & 18.4 & $\pm 1.8^{\mathrm{d}}$ & 15.7 & $\pm 0.9^{\mathrm{c}}$ & 14.1 & $\pm 1.0^{\mathrm{ab}}$ & 13.2 & $\pm 0.8^{\mathrm{a}}$ & $* *$ & n.s. & n.s. \\
\hline $18: 1 n-7$ & 4.4 & $\pm 0.3^{b}$ & 4.7 & $\pm 0.3^{\mathrm{b}}$ & 3.5 & $\pm 0.0^{\mathrm{a}}$ & 3.4 & $\pm 0.3^{\mathrm{a}}$ & $* *$ & n.s. & n.s. \\
\hline $20: 1 n-7$ & 1.6 & $\pm 0.1^{\mathrm{b}}$ & 1.2 & $\pm 0.0^{\mathrm{a}}$ & 1.4 & $\pm 0.2^{\mathrm{ab}}$ & 1.3 & $\pm 0.1^{\mathrm{a}}$ & n.s. & $* *$ & n.s. \\
\hline $22: 1 n-11$ & 0.8 & $\pm 0.1^{\mathrm{c}}$ & 0.5 & $\pm 0.0^{\mathrm{b}}$ & 0.3 & $\pm 0.0^{\mathrm{a}}$ & 0.3 & $\pm 0.0^{\mathrm{a}}$ & $* *$ & $* *$ & $*$ \\
\hline$\Sigma$ Monosaturated $^{\ddagger}$ & 28.9 & $\pm 2.8^{\mathrm{b}}$ & 25.2 & $\pm 1.5^{\mathrm{a}}$ & 23.6 & $\pm 1.7^{\mathrm{a}}$ & 22.6 & $\pm 1.8^{\mathrm{a}}$ & $*$ & n.s. & n.s. \\
\hline $18: 2 n-6$ & 12.2 & $\pm 0.7^{b}$ & 11.7 & $\pm 0.3^{\mathrm{b}}$ & 8.1 & $\pm 1.1^{\mathrm{a}}$ & 9.0 & $\pm 0.6^{\mathrm{a}}$ & $* *$ & n.s. & n.s. \\
\hline $18: 3 n-6$ & 0.2 & $\pm 0.0^{\mathrm{a}}$ & 0.3 & $\pm 0.0^{\mathrm{b}}$ & 0.1 & $\pm 0.1^{\mathrm{a}}$ & 0.1 & $\pm 0.1^{\mathrm{a}}$ & $* *$ & n.s. & n.s. \\
\hline $20: 2 n-6$ & 0.4 & $\pm \quad 0.0$ & 0.4 & $\pm \quad 0.0$ & 0.5 & $\pm \quad 0.0$ & 0.5 & \pm 0.1 & n.s. & n.s. & n.s. \\
\hline $20: 3 n-6$ & 0.2 & $\pm 0.0^{\mathrm{a}}$ & 0.3 & $\pm 0.0^{\mathrm{ab}}$ & 0.3 & $\pm 0.1^{\mathrm{b}}$ & 0.5 & $\pm 0.1^{\mathrm{c}}$ & $* *$ & $*$ & n.s. \\
\hline $20: 4 n-6$ & 1.9 & $\pm 0.4^{\mathrm{a}}$ & 2.1 & $\pm 0.2^{\mathrm{a}}$ & 3.6 & $\pm 0.5^{\mathrm{b}}$ & 4.1 & $\pm 0.4^{\mathrm{b}}$ & $* *$ & n.s. & n.s. \\
\hline$\Sigma$ n-6PUFA ${ }^{\S}$ & 15.2 & $\pm 1.2^{\mathrm{b}}$ & 15.4 & $\pm 1.1^{\mathrm{b}}$ & 12.9 & $\pm 1.8^{\mathrm{a}}$ & 14.7 & $\pm 1.3^{\mathrm{b}}$ & $* *$ & $*$ & n.s. \\
\hline $18: 3 n-3$ & 7.5 & $\pm 0.7^{\mathrm{b}}$ & 11.1 & $\pm 1.9^{c}$ & 0.5 & $\pm 0.1^{\mathrm{a}}$ & 0.5 & $\pm 0.0^{\mathrm{a}}$ & $* *$ & $*$ & $*$ \\
\hline $18: 4 n-3$ & 0.9 & $\pm 0.1^{\mathrm{b}}$ & 1.4 & $\pm 0.4^{\mathrm{c}}$ & 0.1 & $\pm 0.0^{\mathrm{a}}$ & 0.1 & $\pm 0.0^{\mathrm{a}}$ & $* *$ & n.s. & n.s. \\
\hline $20: 3 n-3$ & 0.6 & $\pm 0.0^{\mathrm{b}}$ & 0.9 & $\pm 0.1^{\mathrm{c}}$ & 0.1 & $\pm 0.0^{\mathrm{a}}$ & 0.1 & $\pm 0.0^{\mathrm{a}}$ & $* *$ & $* *$ & $* *$ \\
\hline $20: 4 n-3$ & 0.6 & $\pm 0.0^{\mathrm{b}}$ & 0.7 & $\pm 0.1^{\mathrm{c}}$ & 0.2 & $\pm 0.1^{\mathrm{a}}$ & 0.2 & $\pm 0.0^{\mathrm{a}}$ & $* *$ & n.s. & $* *$ \\
\hline $20: 5 n-3$ & 3.9 & \pm 0.6 & 3.0 & \pm 0.5 & 3.1 & \pm 1.0 & 3.1 & \pm 0.5 & n.s. & n.s. & n.s. \\
\hline
\end{tabular}




\begin{tabular}{|c|c|c|c|c|c|c|c|c|c|c|c|c|c|c|}
\hline $22: 5 n-3$ & 1.3 & $\pm 0.3^{b}$ & 0.7 & \pm & $0.0^{\mathrm{a}}$ & 1.7 & \pm & $0.5^{\mathrm{b}}$ & 1.3 & \pm & $0.2^{\mathrm{b}}$ & $*$ & $*$ & n.s. \\
\hline $22: 6 n-3$ & 11.6 & $\pm 2.8^{\mathrm{a}}$ & 9.7 & \pm & $1.9^{\mathrm{a}}$ & 17.2 & \pm & $4.5^{\mathrm{b}}$ & 19.6 & \pm & $4.1^{b}$ & $*$ & n.s. & n.s. \\
\hline$\Sigma$ n-3PUFA ${ }^{\pi}$ & 26.4 & \pm 5.7 & 27.7 & \pm & 4.9 & 22.9 & \pm & 7.2 & 24.8 & \pm & 4.9 & $*$ & n.s. & n.s. \\
\hline$\Sigma$ n-9PUFA ${ }^{\dagger \dagger}$ & 19.2 & $1.9^{\mathrm{b}}$ & 16.5 & & $0.9^{\mathrm{a}}$ & 15.2 & & $1.2^{\mathrm{a}}$ & 14.4 & & $1.1^{\mathrm{a}}$ & $* *$ & n.s. & n.s. \\
\hline$(n-3+n-6)$ PUFA & 41.7 & \pm 6.9 & 43.1 & \pm & 6.1 & 35.9 & \pm & 9.0 & 39.8 & \pm & 6.2 & $* *$ & $*$ & n.s. \\
\hline Total n-3 LC-PUFA & 17.4 & $\pm 4.9^{\mathrm{ab}}$ & 14.2 & \pm & $2.5^{\mathrm{a}}$ & 22.2 & \pm & $5.1^{\mathrm{ab}}$ & 24.2 & \pm & $4.8^{\mathrm{b}}$ & $*$ & n.s. & n.s. \\
\hline
\end{tabular}

Data expressed as means of three technical replicates per batch of larvae. Includes 15:0 and 17:0. ${ }^{ \pm}$Includes 14:1n-7. 14:1n-5. 15:1n-5. 16:1n-5. 18:1n-5. 20:1n-9. and 20:1n-5. SIncludes. 22:5n-6 and 22:4n-6. Includes 16:3n-3 and 16:4n-3. ${ }^{\dagger}$ Includes. 22:1n-9.

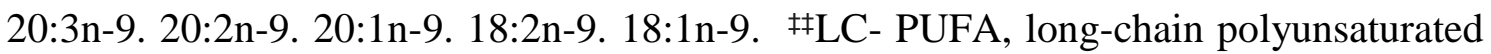
fatty acid (sum of 20:4n-3, 20:5n-3 22:5n-3 and 22:6n-3). LP, live prey; EN, enrichment; $\mathrm{LP} * \mathrm{EN}$, interaction between live prey and enrichment. Different superscript letters denote differences among treatments identified by one-way ANOVA.

$* \mathrm{p}<0.05$.

$* * \mathrm{p}<0.01$

\section{Discussion}

Significant differences in terms of dry weight, SGR and total length were observed at $30 \mathrm{dph}$ being higher in meagre larvae fed with the combination of rotifers, Artemia and microdiets (diets RS and RO) regardless of the enrichment media used. Survival was also significantly higher in those larvae fed with Artemia (19.5\% RAS and $17.8 \%$ RAO) compared with larvae fed rotifers only (14.8\% RS and $12.8 \%$ RO). Similar results were obtained by Fernández-Palacios, Hernández-Cruz, Schuchardt, Izquierdo \& Roo (2009) who showed that meagre larvae were significantly larger, and the survival was higher when co-fed with Artemia instead of rotifers only. The energy that is required to breakdown, absorb, transport and assimilate nutrients from a meal adds up to $25 \%$ of the daily energy expenditures in fish (Secor, 2011). As larvae grow, the range of accessible particle size increase, however, the ingested prey also needs to supply mass and energy. The growing larvae try to ingest the maximum quantity of nutrients required for growth, while maintaining a favourable ratio between the energy gained by the ingestion of the prey and the energy spent in the capture (Herbing, Gallager \& Halteman, 2001; Puvanendran, Salies, Laurel \& Brown, 2004). The lack of Artemia in the feeding sequence lead to poor survival and growth probably because of a high energy cost/benefit related to the small size of the prey (rotifers), indicating that it is necessary an intermediate feeding between rotifers and microdiet. The present study suggests that it is possible to wean meagre larvae directly from rotifer to an inert feed from 20 dph (survival 12.8$14.8 \%$ ), but a co-feeding period with Artemia implies higher survival and growth of the 
larvae. Survival and growth results were in the same range as those reported by Estevez et al. (2007) and Rodríguez-Rúa et al. (2007) for the same teleost species.

Apart from larvae performance, one of the aims of the present study was to assess the first appearance of granulomas in meagre larvae (10 to $30 \mathrm{dph}$ ). To the authors knowledge this is the first report of systemic granulomatosis in meagre larvae. Specifically, the first observation of microscopic granulomas was at $20 \mathrm{dph}$ on fish fed with rotifer only either enriched with Selco (RS; $1.3 \%)$ or with Ori-Green (RO; $2.0 \%)$. On the contrary, fish fed with Artemia did not show any granuloma until 30 dph (only $0.7 \%$ incidence; RAO-fed larvae). However, after 30 dph significant differences were observed in the percentage of granulomas among the dietary treatments, being higher in fish fed diet RO and RS (15.7 and $10.7 \%$, respectively) compared with fish fed RAO and RAS (0.7 and $0.0 \%$, respectively). In the present study, the concentration of vitamin $\mathrm{E}$ in rotifers (310.1-179.9 mg kg-1) was lower than in Artemia (410.7 and $368.0 \mathrm{mg} \mathrm{kg}^{-1}$ ) and was also influenced by the enrichment media, being higher the concentration in the diets RAS and RS compared with RAO and RO. The vitamin content of rotifer and Artemia has been previously studied by Meeren, Olsen, Hamre \& Fyhn, (2008) being the level of vitamin E slightly lower in rotifer but those of vitamin C clearly lower $(220.1 \mu \mathrm{g}$ $\left.\mathrm{g}^{-1}\right)$ compared with Artemia $\left(530.6 \mu \mathrm{g} \mathrm{g}^{-1}\right)$. Vitamin $\mathrm{C}$ is a powerful antioxidant and its deficiency has been related with the appearance of granulomas in turbot (Messager et al., 1986; Coustans et al., 1990), sea bream (Alexis et al., 1997) and meagre (Ruiz et al., 2018). The lack of Artemia in the feeding sequence increased the appearance of granulomas in meagre larvae after $30 \mathrm{dph}$ (diets RO and RS) related likely with the differences in antioxidant vitamins of the live prey. Nevertheless, feeding with enriched rotifer, followed by enriched Artemia and microdiet, could prevent the occurrence of granulomas in meagre larvae after $30 \mathrm{dph}$ (diet RAS), being the period before feeding with microdiet, a critical point to the development of systemic granulomatosis in meagre.

Besides, in the present study the appearance of systemic granulomatosis was highly correlated with TBARS content in meagre larvae $\left(\mathrm{R}^{2}=0.948, \mathrm{y}=0.084 \mathrm{x}-4.3924\right)$, corroborating a possible relationship between lipid peroxidation and the appearance of granulomas. In this sense, TBARS levels were significantly higher in meagre larvae fed with rotifers only and microdiet (282.9-288.0 $\mu \mathrm{mol} g$ tissue $\left.{ }^{-1}\right)$ compared with larvae fed with rotifer, Artemia and microdiet (56.8-67.4 $\mu \mathrm{mol} \mathrm{g}$ tissue ${ }^{-1}$ ). Moreover, a higher incidence of granulomas was observed at $30 \mathrm{dph}$ in meagre larvae fed diets RS (10.7\%) 
and RO (15.7\%) with less analysed vitamin E contents in the diet (310.1 and $179.9 \mathrm{mg}$ $\mathrm{kg}^{-1}$, respectively) than in diets RAS $(0 \%)$ and RAO $(0.7 \%)$ with higher concentration of vitamin E (410.7 and $368.0 \mathrm{mg} \mathrm{kg}^{-1}$, respectively). Betancor et al. (2011) observed that in sea bass (Dicentrarchus labrax) larvae the supplementation of vitamin E up to 3,000 mg $\mathrm{kg}^{-1}$ diet had an antioxidant effect reducing TBARS values, decreasing lipid peroxidation and reducing the incidence of muscular lesions. In juveniles of meagre, the dietary increase of vitamin $\mathrm{E}$ and $\mathrm{C}$ lead to a reduction in the percentage and severity of granulomas in liver and heart together with a decrease in TBARS content (Ruiz et al., 2018), suggesting that these vitamins have an important role in the development of systemic granulomatosis in this species.

El Kertaoui et al. (2017) determined that the requirements of n-3 PUFA for meagre larvae were a $3 \%$ (1.5-1.7 \% DHA) in order to improve lipid absorption, fatty acid profile and growth. The levels of n-3 PUFA in all diets in the present study probably fulfilled the requirements However, these fatty acids, specially DHA, are very prone to oxidation (Izquierdo et al., 2013) being necessary an adequate level of antioxidant nutrients to avoid lipid peroxidation. The combination of a high concentration of DHA together with low vitamin $\mathrm{E}$ and $\mathrm{C}$ levels can lead to an imbalance between prooxidant and antioxidant nutrients, as observed in a higher TBARS values in meagre larvae fed diets RO and RS. When an imbalance between the generation and removal of ROS by cellular defences occurs a status of oxidative stress takes place. The oxidative stress has been related with some diseases such as haemolysis (Kawatsu, 1969), anaemia, liver degeneration (Cowey, Degener, Tacon, Youngson \& Bell, 1984), jaundice (Sakai et al., 1989), skeletal alterations (Watanabe, Izquierdo, Takeuchi, Satoh \& Kitajima, 1989; Lewis-McCrea \& Lall, 2007) or muscular dystrophy (Betancor et al., 2012). In agreement, the results of this study suggest that the systemic granulomatosis could be related to this imbalance. Vitamin E also seems to be related with the development of granulomas, as larvae fed with RAO and RO (enrichment media with the lowest vitamin E content) had a higher incidence of granulomas compared with larvae fed RAS and RS. On the other hand, the systemic granulomatosis in meagre is similar to the pathology produced by infectious agents such as Mycobacterium spp. (Gauthier \& Martha, 2009) and Nocardia spp. (Labrie et al., 2008; Elkesh et al., 2012). The inability to determinate an infectious origin and the relation observed between the appearance of the systemic granulomatosis and the feeding sequence in meagre larvae reinforce the hypothesis of a nutritional origin of the disease. 
Concluding, the inclusion of Artemia in the feeding sequence of meagre larvae significantly increased dry weight, total length, SGR and survival and reduced the incidence of systemic granulomatosis and TBARS content after $30 \mathrm{dph}$. Furthermore, larvae fed with diet RO and RS, with a higher concentration of DHA and lower vitamin E, had high TBARS values what suggests an imbalance between prooxidants and antioxidants. Feeding larvae with a combination of enriched rotifers and Artemia greatly decreased the incidence of granulomas, not finding any at $20 \mathrm{dph}$ and just a $0.7 \%$ at 30 dph in larvae fed RAO. This is the first study to report the appearance of granulomas in meagre larvae and to determine the implication of antioxidant nutrients in their development. Further investigation is required to understand the pathogenesis of the granulomas as consequence of an imbalance nutritional supply.

\section{Acknowledgements}

This study was funded by the project "Exploring the biological and socioeconomic potential of new/emerging candidate fish species for expansion of the European aquaculture industry (DIVERSIFY)" of the European Commission; Directorate-general for research and Innovation, project no. FP7-KBBE-2013-7, GRANT AGREEMENT NUMBER 603121. This project has received funding from the European Union's Horizon 2020 research and innovation programme under grant agreement No 652831.

\section{References}

Ai, Q., Mai, K., Tan, B., Xu, W., Zhang, W., Ma, H., \& Liufu, Z. (2006). Effects of dietary vitamin C on survival, growth, and immunity of large yellow croaker, Pseudosciaena crocea. Aquaculture, 261, 327336. https://doi.org/10.1016/j.aquaculture.2006.07.027

Alexis, M. N., Karanikolas, K. K., \& Richards, R. H. (1997). Pathological findings owing to the lack of ascorbic acid in cultured gilthead bream (Sparus aurata L.). Aquaculture, 151, 209-218. https://doi.org/10.1016/S0044-8486(96)01475-5

AOAC (2010). Officials Methods of Analysis (17 $7^{\text {th }}$ Edn). Association of Official Analytical Chemists. Washington, D. C., U.S.A.

Betancor, M. B., Atalah, E., Caballero, M. J., Benítez-Santana, T., Roo, J., Montero, D., \& Izquierdo, M. S. (2011). $\alpha$-Tocopherol in weaning diets for European sea bass (Dicentrarchus labrax) improves survival and reduces tissue damage caused by excess dietary DHA contents. Aquaculture Nutrition, 17, 112-122. https://doi.org/10.1111/j.1365-2095.2009.00741.x

Betancor, M. B., Caballero, M. J., Terova, G., Corà, S., Saleh, R., Benítez-Santana, T., Bell, J. G., Hernández-Cruz, C. M., \& Izquierdo M. (2012). Vitamin C enhances vitamin E status and reduces oxidative stress indicators in sea bass larvae fed high DHA microdiets. Lipids, 47, 1193-1207. https://doi.org/10.1007/s11745-012-3730-X 
Boglino, A., Darias, M. J., Ortiz-Delgado, J. B., Ozcan, F., Estevez, A., Andree, K. B., Hontoria, F., Sarasquete, C., \& Gisbert, E. (2012). Commercial products for Artemia enrichment affect growth performance, digestive system maturation, ossification and incidence of skeletal deformities in Senegalese sole (Solea senegalensis) larvae. Aquaculture, 324-325, 290-302. https://doi.org/10.1016/j.aquaculture.2011.11.018

Burk, R. F, Trumble, M. J., \& Lawrence, R. A. (1980). Rat hepatic cytosolic GSH-dependent enzyme protection against lipid peroxidation in the NADPH microsomal lipid peroxidation system. Biochimica et Biophysica Acta, 618, 35-41. https://doi.org/10.1016/0005-2760(80)90051-X

Cadenas, E. (1989). Biochemistry of oxygen toxicity. Annual Review of Biochemistry, 58, 79-110. https://doi.org/10.1146/annurev.bi.58.070189.000455

Carvalho, M., Peres, H., Saleh, R., Fontanillas, R., Rosenlund, G., Oliva-Teles, A., \& Izquierdo, M. (2018). Requirements for n-3 HUFA of meagre (Argyrosomus regius, asso, 1801) fingerlings. $18^{\text {th }}$ International Symposium on Fish Nutrition and Feeding, 3-7 June 2018, Las Palmas de Gran Canaria, Spain.

Christie, W. W. (1982) . Lipid Analysis, Pergamon, Oxford.

Cotou, E., Fountoulaki, E., Hager-Theodorides, A. L., Theodorou, G., Tsertou, M., Loukanari, T., Katharios, P., \& Kounna, C. H. (2016). The effects of dietary inclusions of vitamin D3 associated to CYP27A1, antioxidant enzymes and non-infectious systemic granulomatosis in meagre (Argyrosomus regius). International Symposium on Fish Nutrition and Feeding, 5-10, 2016, Sun Valley, Idaho.

Coustans, M. F., Guillaume, J., Metailler, R., Dugornay, O., \& Messager, J. L. (1990). Effect of an ascorbic acid deficiency on tyrosinemia and renal granulomatous disease in turbot (Scophthalmus maximus) interaction with a slight polyhypovitaminosis. Comparative Biochemistry and Physiology, 97, 145-52. https://doi.org/10.1016/0300-9629(90)90161-K

Cowey, C. B., Degener, E., Tacon, A. G. J., Youngson, A., \& Bell, J. G. (1984). The effects of vitamin E and oxidised fish oil on the nutrition of rainbow trout (Salmo gairdneri) grown at natural, varying water temperature. British Journal of Nutrition 51, 443-451. https://doi.org/10.1079/BJN19840050

Duncan, N. J., Estévez, A., Fernández-Palacios, H., Gairin, I., Hernández-Cruz, C. M., Roo, J., Schuchardt, D. \& Vallés, R. (2013). Aquaculture production of meagre (Argyrosomus regius): hatchery techniques, ongrowing and market. In: Allan, G., Burnell, G. (Eds.), Advances in aquaculture hatchery technology (pp 519-541. Woodhead Publishing Limited, Cambridge, UK. https://doi.org/10.1533/9780857097460.3.519

El Kertaoui, N., Hernández-Cruz, C. M., Montero, D., Caballero, M. J., Saleh, R., Afonso, J. M. and Izquierdo, M. (2017). The importance of dietary HUFA for meagre larvae (Argyrosomus regius; Asso, 1801) and its relation with antioxidant vitamins E and C. Aquaculture Research, 48, 419-433. https://doi.org/10.1111/are.12890

Elkesh, A., Kantham, K. P. L., Shinn, A. P., Crumlish, M., \& Richards, R. H. (2012). Systemic nocardiosis in a Mediterranean population of cultured meagre, Argyrosomus regius Asso (Perciformes: Sciaenidae). Journal of Fish Diseases, 36, 141-149. https://doi.org/10.1111/jfd.12015

El-Shebly A., El-Kady, M. A. H., Hussin, A., \& Yeamin Hossain, M. D. (2007). Preliminary observations on the pond culture of meagre Argyrosomus regius (Asso, 1801) (Sciaenidae) in Egypt. Journal of Fisheries and Aquatic Science, 2, 345-352. https://scialert.net/abstract/?doi=jfas.2007.345.352

Estevez, A., Treviño, L., \& Gisbert, E. (2007). La densidad larvaria inicial afecta al crecimiento pero no a la supervivencia de las larvas de corvina (Argyrosomus regius) en cultivo. In: Libro de Actas XI Congreso Nacional de Acuicultura, A. Cerviño Eiroa, A. Guerra Díaz, C. Pérez and Acosta (Eds.). pp. 747-749. Gráficas Salnés, S.L. Vigo, España, 24-28 septiembre 2007.

Fernández-Palacios, H., Hernández-Cruz, C. M., Schuchardt, D., Izquierdo, M. S., \& Roo, F. J. (2009). Effect of co-feeding regimes on biological performance and biochemical composition of meagre (Argyrosomus regius asso, 1801) larvae. In: Larvi' 09 - 5th Fish \& Shellfish Larviculture Symposium (ed. by C.I. Hendry, G. Van Stappen, M. Wille \& P. Sorgeloos), European Aquaculture Society, Special Publication, 38, 108-110, Oostende, Belgium. 
Fite, G. L., Cambre, F. J., \& Turner, M. H. (1947). Procedures for demonstrating lepra bacilli in paraffin sections. Archives of Pathology, 43, 624-625.

Folch, J. M., Lees M., \& Stanley Sloane, G. H. (1957). A simple method for the isolation and purification of total lipids from the animal tissues. The Journal of Biological Chemistry, 226, 497-509.

Gauthier, D. T., \& Martha, W. R. (2009). Mycobacteriosis in fishes: A review. The Veterinary Journal, 180, 33-47, https://doi.org/10.1016/j.tvj1.2008.05.012

Gao J., Koshio, S., Ishikawa, M., Yokoyama, S., \& Edward, R. (2014). Interactive effects of vitamin C and E supplementation on growth performance, fatty acid composition and reduction of oxidative stress in juvenile Japanese flounder Paralichthys olivaceus fed dietary oxidized fish oil. Aquaculture, 422-423, 84-90. https://doi.org/10.1016/j.aquaculture.2013.11.031

Ghittino, C., Manuali, E., Latini, M., Agnetti, F., Rogato, F., Agonini, R., Colussi, S., \& Prearo, M. (2004). Caso di granulomatosi sistemica in ombrina boccadoro (Argyrosomus regius) e raffronto con le lesioni istologiche presenti nell'orata. Ittiopatologia, 1, 59-67.

Gregersen, T. (1978). Rapid method for distinction of gram-negative from gram-positive bacteria. European journal of applied microbiology and biotechnology, 5, 123-127.

Hamre, K., Krossoy, C., Lock, E. J., \& Moren, M. (2010.) Roles of lipid - soluble vitamins during ontogeny of marine fish larvae. Aquaculture Research, 41, 745-750. https://doi.org/10.1111/j.13652109.2009.02375.x

Hemre, G. I., Mangor-Jensen, A., \& Lie, Ø. (1994). Broodstock nutrition in turbot (Scophthalmus maximus) effect of dietary vitamin E. Fiskeridir. Skr. Ser. Ernaer, 8, 21-29.

Herbing, I, Gallager, S.M., \& Halteman, W. (2001). Metabolic cost of pursuit and attack in early larval Atlantic cod. Marine Ecology Progress Series, 216, 201-212. https://doi.org/10.3354/meps216201

Huervana, F. H., De La Cruz, J. J. Y., \& Caipang, C. M. A. (2006). Inhibition of luminous Vibrio harveyi by "green water" obtained from tank culture of Tilapia, Oreochromis mossambicus. Acta Ichthyologica Et Piscatoria, 36, 17-23. http://dx.doi.org/10.3750/AIP2006.36.1.03

Izquierdo, M. S., Arakawa, T., Takeuchi, T., Haroun, R., \& Watanabe, T. (1992). Effect of n-3 HUFA levels in Artemia on growth of larval Japanese flounder (Paralichthys olivaceous). Aquaculture, 105, 73-82. https://doi.org/10.1016/0044-8486(92)90163-F

Izquierdo, M. S., Scolamacchia, M., Betancor, M., Roo, J., Caballero, M. J., Terova, G., \& Witten, P. (2013). Effects of dietary DHA and $\alpha$-tocopherol on bone development, early mineralisation and oxidative stress in Sparus aurata (Linnaeus, 1758) larvae. British Journal of Nutrition, 109, 1796-1805. https://doi.org/10.1017/S0007114512003935

Jiménez, M. T, Pastor, E., Grau, A., Alconchel, E., \& Cárdenas, S. (2005). Revisión sobre el cultivo de esciénidos en el mundo, con especial atención a la corvina (Argyrosomus regius). Boletín Instituto Español de Oceanografía, ISSN 0212-1565, 21 169-176.

Kawatsu, H. (1969). Studies on the anemia of fish-III. An example of macrocyticanemia found in brook trout, Salvelinus fontinalis. Bulletin of Freshwater Fisheries Research Laboratory 19, 161-167.

Kolkovski, S., Czesny, S., Yackey, C., Moreau, R., Cihla, F., \& Mahan, D. (2000). The effect of vitamins $\mathrm{C}$ and $\mathrm{E}$ in (n-3) highly unsaturated fatty acids-enriched Artemia nauplii on growth, survival and stress resistance of fresh water walley Stizostedion vitreum larvae. Aquaculture Nutrition, 6, 199-206. https://doi.org/10.1046/j.1365-2095.2000.00112.x

Labrie, L., Ng, J., Tan, Z., Komar, C., Ho, E., \& Grisez, L. (2008). Nocardial infections in fish: an emerging problem in both freshwater and marine aquaculture systems in Asia. In: Diseases in Asian Aquaculture VI (ed. by M.G. Bondad-Reantaso, C.V. Mohan, M. Crumlish \& R.P. Subasinghe), Fish Health Section, Asian Fisheries Society (pp. 297-312). Manila, Philippines. 
Lewis-McCrea, L. M., \& Lall, S. P. (2007). Effects of moderately oxidized dietary lipid and the role of vitamin $\mathrm{E}$ on the development of skeletal abnormalities in juvenile atlantic halibut (Hippoglossus hippoglossus). Aquaculture, 262, 142-155. https://doi.org/10.1016/j.aquaculture.2006.09.024

Lie, Ø., Sandvin, A., \& Waagbø, R. (1994). Transport of alpha-tocopherol in Atlantic salmon (Salmo salar) during vitellogenesis. Fish Physiology and Biochemistry, 13, 241-247. https://doi.org/10.1007/BF00004362

Martoja, R., \& Martoja-Pearson, M. (1970). Técnicas de Histología Animal (1ed.). Toray-Masson S.A., Barcelona.

McMurray, C. H., Blanchflower, W. J., \& Rice, D. A. (1980). Influence of extraction techniques on determination of $\alpha$-tocopherol in animal feedstuffs. Journal of the Association of Official Analytical Chemists 63, 1258-1261.

Meeren, T., Olsen, R. E., Hamre, K., \& Fyhn, H. J., (2008). Biochemical composition of copepods for evaluation of feed quality in production of juvenile marine fish. Aquaculture, 274, 375-397. https://doi.org/10.1016/j.aquaculture.2007.11.041

Merchie, G., Lavens, P., \& Sorgeloos, P. (1997). Optimization of dietary vitamin C in fish and crustacean larvae: a review. Aquaculture, 155, 165-181. https://doi.org/10.1016/S0044-8486(97)00115-4

Messager, J. L., Ansquer, D., Metailler, R., J., \& Person-Le-Ruvet, J. (1986). Experimental induction of the "granulomatous hypertyrosinemia" of reared turbot (Scophthalmus maximus) with an ascorbic acid deficient diet. Ichtyophysiologica Acta, 10, 201-214.

Montero, D., Marrero, M., Izquierdo, M. S., Robaina, L., Vergara, J. M., \& Tort, L. (1999). Effect of vitamins $\mathrm{E}$ and $\mathrm{C}$ dietary supplementation on some immune parameters of gilthead seabream (Sparus aurata) juveniles subjected to crowding stress. Aquaculture, 171, 269-78. https://doi.org/10.1016/S0044-8486(98)00387-1

Mukhopadhyay, P. K., Chattopadhyay, D. N., \& Mitra, G. (2003). Broodstock nutrition, the key to quality seed production. Infofish International., 3, 25-34.

Nakase, G., Nakagawa, Y., Miyashita, S., Nasu, T., Senoo, S., Matsubara, H., \& Eguchi, M. (2007). Association between bacterial community structures and mortality of fish larvae in intensive rearing systems. Fisheries Science, 73, 784-791. https://doi.org/10.1111/j.1444-2906.2007.01397.x

NRC. (2011). Nutrient Requirements of Fish and Shrimp. National Academic Press, Washington D.C.

Øie, G., Makridis, P., Reitan, K. I., \& Olsen, Y. (1997). Protein and carbon utilization of rotifers (Brachionus plicatilis) in first feeding of turbot larvae (Scophthalmus maximus L.). Aquaculture, 153, 103-122. https://doi.org/10.1016/S0044-8486(96)01514-1

Poli, B. M., Parisi, G., Zampacavallo, G., Iurzan, F., Mecatti, M., Lupi, P., \& Bonelli, A. (2003). Preliminary results on quality and quality changes in reared meagre (Argyrosomus regius): body and fillet traits and freshness changes in refrigerated commercial-size fish. Aquaculture International, 11, 301-311. https://doi.org/10.1023/A:1024840804303

Puvanendran, V., Salies, K., Laurel, B., \& Brown, J. A. (2004). Sizedependent foraging on larval Atlantic cod (Gadus morhua). Canadian Journal of Zoology, 82, 1380-1389. https://doi.org/10.1139/z04-114

Reitan, K. I., Rainuzzo, J. R., Øie, G., \& Olsen, Y. (1997). A review of the nutritional effects of algae in marine fish larvae. Aquaculture, 155, 207-221. https://doi.org/10.1016/S0044-8486(97)00118-X

Rodríguez-Rúa, A., Grau, A., Jiménez, M. T., Valencia, J. M., Rosano, M., Durán, J., Pastor, E., \& Cárdenas, S. (2007). Cultivo larvario de la corvina Argyrosomus regius (Asso, 1801). In: Cerviño, A., Guerra, A., Pérez, C. (Eds.), Actas XI Congreso Nacional de Acuicultura. Gráficas Salnés, Vigo, España, pp. 739742. 
Roo, J., Hernandez-Cruz, C. M., Borrero, C., Schuchardt, D., \& Fernandez-Palacios, H. (2010). Effect of larval density and feeding sequence on meagre (Argyrosomus regius, Asso, 1801) larval rearing. Aquaculture, 302, 82-88. https://doi.org/10.1016/j.aquaculture.2010.02.015

Ruiz, M. A., Betancor, M. B., Robaina, L., Montero, D., Hernández-Cruz, C. M., Izquierdo, M, Rosenlund, G., Fontanillas, R., \& Caballero M. J. (2018). Dietary combination of vitamin E, C and K affects growth, antioxidant activity, and the incidence of systemic granulomatosis in meagre (Argyrosomus regius). Aquaculture, 498, 606-620. https://doi.org/10.1016/j.aquaculture.2018.08.078

Sakai, T., Murata, H., Endo, M., Yamauchi, K., Tabata, N., \& Fukudome, M. (1989). 2-Thiobarbituric acid values and contents of $\alpha$-tocopherol and bile pigments in the liver and muscle of jaundiced yellowtail, Seriola quinqueradiata. Agricultural and Biological Chemistry, 53, 1739-1740. https://doi.org/10.1080/00021369.1989.10869531

Secor, S. M. (2011). Food acquisition and digestion: Cost of digestion and assimilation. Encyclopedia of Fish Physiology, 3, 1608-1616. https://doi.org/10.1016/B978-0-12-374553-8.00143-X

Skřivan, M., Marounek, M., Englmaierová, M., \& Skřivanová, V. (2013). Influence of dietary vitamin C and selenium, alone and in combination, on the performance of laying hens and quality of eggs. Czech Journal of Animal Science, 58, 91-97. https://doi.org/10.17221/6619-CJAS

Stéphan, G., Guillaume, J., \& Lamour, F. (1995). Lipid peroxidation in turbot (Scophthalmus maximus) tissue: effect of dietary vitamin E and dietary n-6 or n-3 polyunsaturated fatty acid. Aquaculture, 130, 251-268. https://doi.org/10.1016/0044-8486(94)00322-F

Stuart, K. R., \& Drawbridge, M. (2001). The effect of light intensity and green water on survival and growth of cultured larval California yellowtail (Seriola lalandi). Aquaculture, 321, 152-156. https://doi.org/10.1016/j.aquaculture.2011.08.023

Støttrup, J. G. (2000). The elusive copepods: their production and suitability in marine aquaculture. Aquaculture Research, 31, 703-711. https://doi.org/10.1046/j.1365-2109.2000.318488.x

Theilacker, G. H., \& McMaster, M. F. (1971). Mass culture of the rotifer Brachionus plicatilis and its evaluation as a food for larval anchovies. Marine Biology, 10, 183-188. https://doi.org/10.1007/BF00354834

Vallés, R., \& Estevez, A. (2013). Light conditions for larval rearing of meagre (Argyrosomus regius). Aquaculture, 376-379, 15-19. https://doi.org/10.1016/j.aquaculture.2012.11.011

Watanabe, T., Izquierdo, M. S., Takeuchi, T., Satoh, S., \& Kitajima, C. (1989). Comparison between eicosapentaenoic and docosahexaenoic acids in terms of essential fatty acids efficacy in larval red seabream. Nippon Suissan Gakkaishi 5, 1635-1640. https://doi.org/10.2331/suisan.55.1635 